\title{
Effects of Feeding Frequency Variation on the Growth and Survival of Clarias gariepinus Fingerlings
}

\author{
Oso, J.A*
}

Zoology Department, Ekiti State University, P.M.B 5363, Ado Ekiti, Nigeria

\begin{tabular}{|c|c|}
\hline Abs & Article Information \\
\hline \multirow{11}{*}{$\begin{array}{l}\text { A 56-day experiment was conducted to consider the effects of feeding frequency variation on } \\
\text { the growth and survival of Clarias gariepinus fingerlings. The frequencies of feeding were } \\
\text { once daily, twice daily, once in two days and once in three designated as G1, G2, G3 and G4 } \\
\text { respectively. One hundred and twenty fingerlings were stocked into } 30 \text { litre plastic aquaria } \\
\text { with each tank stocked with ten fingerlings in three replicates under laboratory conditions. A } \\
\text { commercial feed was used for the feeding trials with the fingerlings fed at } 5 \% \text { body weight. } \\
\text { The fingerlings fed once in three days had the least value of weight and length but were not } \\
\text { significantly different ( } p<0.05) \text {. The fingerlings fed once daily had the highest specific growth } \\
\text { rate (SGR) of } 1.66 \text { and the fingerlings fed once in three days had the least value, which was } \\
\text { significantly different from others. Highest survival rate of } 73.3 \% \text { was recorded in fingerlings } \\
\text { fed once in two days. The study showed that body composition of } C \text {. gariepinus fingerlings } \\
\text { was influenced by the different feeding frequencies. Based on the growth performance } \\
\text { recorded in this research, once in a day feeding frequency was the best to obtain the highest } \\
\text { growth while once in } 2 \text { days feeding frequency gave the best survival value in the African } \\
\text { catfish fingerlings. }\end{array}$} & ory: \\
\hline & Received : 03-06-2015 \\
\hline & Revised \\
\hline & Accepted : 23-09-2015 \\
\hline & \\
\hline & Feeding frequency \\
\hline & Growth \\
\hline & urvival \\
\hline & Clarias gariepinus \\
\hline & $\begin{array}{l}\text { *Corresponding Author: } \\
\text { Oso, J.A }\end{array}$ \\
\hline & \\
\hline
\end{tabular}

\section{INTRODUCTION}

The desire of fish farmers has been to produce table sized fish within the shortest possible time at a reduced the cost of production and maximum profits. Long term success in meeting the desire of having an all year round supply of fish depends on the ability of the farmer to control the entire life cycle of the fish (Ekelemu and Zelibe, 2006). Clarias gariepinus is a commercially important species which according to Idodo-Umeh, (2003), occupies a unique and prominent position in Nigeria because it is tasty, hardy and can tolerate poor water condition.

The cost of fish feed is considered as the highest share of total cost in any intensive aquaculture operation. Therefore, feed quality and feeding strategies are of great importance in fish nutrition science. One problem facing fish culturist is the need to obtain a balance between rapid fish growth and optimum use of the supplied feed (Gokcek et al., 2008). There is also the need to establish the effects of number of feeding times or frequency on food management, nutrient utilization and growth rate of fish. Since the feed cost accounts approximately $40-60 \%$ of the operating cost in intensive culture system (Agung, 2004). The amount of the daily feed intake, frequency and timing of the feeding and predetermined ration are the key factors of feed management strategies influencing the growth and feed conversion. Feeding also at the optimum frequency can result in tremendous saving in feed cost (Davies et al., 2006). According to Hung et al. (2002) fish growth at different stages is largely governed by the kind of feed, feeding frequency, feed intake and its ability to absorb the nutrient among which feeding frequency is an important factor for the survival and growth of fish at the early stage. However, over feeding leads not only to reduction in feed conversion ratio and increase in input cost but also results in accumulation of wastes that adversely affect the water quality (Ekelemu and Ogba, 2005). By controlling the optimum feeding frequency, farmers can successfully reduce the feed cost, maximize growth and also able to manage other factors such as individual size-variation and water qualities which are deemed important in rearing of fish in culture conditions (Cavero, 2004). The objective of the study is to determine the most appropriate feeding frequency in Clarias gariepinus fingerlings with a view to achieving optimum growth and survival at a reasonable cost of production.

\section{MATERIALS AND METHODS}

\section{Fish Specimens}

Fingerlings of African catfish Clarias gariepinus with average weight of $6.6 \pm 0.1 \mathrm{~g}$ were purchased from a hatchery and transported to the laboratory for analysis and experimentation. Materials used in the experiment included plastic tanks (aquaria), siphon pipe, freshwater, fish feed, meter rule, Weigh balance and net mesh.

\section{Feeding Trials}

The feeding trial was performed at the postgraduate laboratory of Zoology Department, Ekiti State University. The fingerlings were randomly distributed into twelve 
Oso

plastic tanks of 30 litres volume at stocking rate of 10 fingerlings per tank grouped into four categories in triplicates. The four groups are G1- fed once a day (at $8.00 \mathrm{am}$ ), G2- fed twice daily (at $8.00 \mathrm{am}$ and $4.00 \mathrm{pm}$ ), G3 fed once in 2 days (at 8.00am) and G4 fed once in 3 days (at $8.00 \mathrm{am}$ ). The period of experiment was 56 days and the fingerlings were fed with compounded fish feed at $42 \%$ crude protein. Standard length was measured to the nearest $0.1 \mathrm{~cm}$ while weight was done to the nearest $0.1 \mathrm{~g}$. The fingerlings were fed at $5 \%$ body weight and feed consumption was monitored. Mortality in each tank was recorded daily and calculated by taking note of the differences in fish numbers between each count. Water quality parameters like $\mathrm{pH}$, temperature and dissolved oxygen were also monitored throughout the period of experiment.

\section{Calculations}

The following formulae were applied to the data:

Specific Growth Rate $(S G R \% /$ day $)=[(\ln W f-W i) / T] \times 100$

$$
\text { Weight gain }(\%)=[(\mathrm{Wf}-\mathrm{Wi}) / \mathrm{Wi}] \times 100
$$

Where $W_{f}$ refers to the mean final weight, $W_{i}$ is the mean initial weight of fish and $T$ is the feeding trial per period in days.
Sci. Technol. Arts Res. J., July-Sep 2015, 4(3): 98-100

\section{Statistical Analysis}

Data analysis was done using ANOVA and Duncan's Multiple Range Test (DMRT) was used for the mean separation.

\section{RESULTS}

Table 1 shows growth and survival of Clarias gariepinus fingerlings fed at different feeding frequencies. At the commencement of the feeding regimes, initial mean weights were taken to be $7.15,6.70,6.25$, and $6.44 \mathrm{~g}$ for G1, G2, G3 and G4 respectively. The mean weights of the four groups were not significantly different $(p>0.05)$. At the end of the feeding regimes, the mean weights of fingerlings varied from $12.95 \mathrm{~g}$ in $\mathrm{G} 4$ as the lowest to $18.15 \mathrm{~g}$ in $\mathrm{G} 1$ being the highest with apparent significant differences $(p<0.05)$ among the four groups. The final mean length which ranged from $12.35 \mathrm{~cm}$ in $\mathrm{G} 4$ to $15.25 \mathrm{~cm}$ in $\mathrm{G} 1$, showed significant differences $(p<0.05)$. The mean weight gain ranged from $6.51 \mathrm{~g}$ in $\mathrm{G} 4$ to $11 \mathrm{~g}$ in G1 with significant differences among the groups at $p<0.05$. The Specific Growth Rate (SGR) recorded in G1 had the highest value of $1.66 \pm 0.09$ while $\mathrm{G} 4$ gave the lowest value of $1.25 \pm 0.02$. There was no significant difference $(p>0.05)$ among the groups. There were significant differences among the four groups with respect to rate of survival. The highest percentage survival rate of $73.3 \%$ was recorded in $\mathrm{G} 3$ while the $\mathrm{G} 2$ gave the poorest rate of $30 \%$.

Table 1: Growth and survival of $C$. gariepinus fingerlings fed at different feeding frequency for eight weeks

\begin{tabular}{cccccccc}
\hline Treatments & $\begin{array}{c}\text { Initial mean } \\
\text { Weight (g) }\end{array}$ & $\begin{array}{c}\text { Final mean } \\
\text { Weight (g) }\end{array}$ & $\begin{array}{c}\text { Mean weight } \\
\text { Gain (g) }\end{array}$ & SGR \% & $\begin{array}{c}\text { Initial mean } \\
\text { Length (cm) }\end{array}$ & $\begin{array}{c}\text { Final mean } \\
\text { Length (cm) }\end{array}$ & $\begin{array}{c}\text { Survival } \\
\text { Rate \% }\end{array}$ \\
\hline G1 & $7.15 \pm 0.67^{\mathrm{a}}$ & $18.15 \pm 1.06^{\mathrm{a}}$ & $11 \pm 1.00^{\mathrm{a}}$ & $1.66 \pm 0.09^{\mathrm{a}}$ & $6.24^{\mathrm{a}}$ & $15.25^{\mathrm{a}}$ & $46.7^{\mathrm{c}}$ \\
G2 & $6.7 \pm 0.11^{\mathrm{b}}$ & $15.20 \pm 0.84^{\mathrm{b}}$ & $8.5 \pm 1.47^{\mathrm{b}}$ & $1.46 \pm 0.07^{\mathrm{a}}$ & $5.57^{\mathrm{b}}$ & $13.65^{\mathrm{b}}$ & $30.0^{\mathrm{d}}$ \\
G3 & $6.25 \pm 0.65^{\mathrm{b}}$ & $13.1 \pm 0.66^{\mathrm{c}}$ & $6.87 \pm 0.23^{\mathrm{c}}$ & $1.33 \pm 0.05^{\mathrm{a}}$ & $5.75^{\mathrm{b}}$ & $12.55^{\mathrm{c}}$ & $73.3^{\mathrm{a}}$ \\
G4 & $6.44 \pm 0.08^{\mathrm{b}}$ & $12.95 \pm 0.64^{\mathrm{c}}$ & $6.51 \pm 1.43^{\mathrm{c}}$ & $1.25 \pm 0.02^{\mathrm{a}}$ & $4.98^{\mathrm{c}}$ & $12.35^{\mathrm{c}}$ & $70^{\mathrm{b}}$ \\
\hline
\end{tabular}

Means with the same superscript are not significantly different across columns at $P>0.05$

\section{DISCUSSION}

Bascinar et al., (2007) reported that fish species have shown that fish consumption and growth generally increased with feeding frequency up to a given limit. This is however contrary to the findings of this present study in which the highest specific growth rate of $1.66 \pm 0.09$ and highest final mean length of 15.25 were recorded in G1. Aderolu et,al,. (2010) reported that SGR was at best at a higher feeding frequency of at least three times daily in the fingerlings of Clarias gariepinus (Burchell 1822) which is at variance to the outcome of this study. Also, mean weight gain of $11 \pm 1.00$ in $\mathrm{G} 1$ did not agree with the findings of Aderolu et al.,(2010) and Ndome et al., (2011) who reported increasing weight gain with increasing feeding frequency. Although $\mathrm{G} 1$ had the highest fish length increment in this study, it still did not follow expected pattern with respect to increasing feeding frequencies. Survival rate of $30 \%$ in G2 contrasted with the findings of Marimuthu et al., (2010) who reported the poorest survival rate in the group fed once daily in their study on the same fish species. According to Marimuthu et al.,(2010), fish species normally exhibit a rapid increase in activity during feeding suggesting that stress may result due to continuous feeding causing the fish to expend energy and consequently reducing growth rate.

\section{CONCLUSION}

The study showed that body composition of $C$. gariepinus fingerlings was influenced by the different feeding frequencies. Based on the growth performance recorded in this research, once in a day feeding frequency was the best to obtain the highest growth while once in 2 days feeding frequency gave the best survival value in the African catfish fingerlings. The outcome of this study calls for further investigation in order to achieve an optimum result that will enhance fish productivity and sustainable profitability.

\section{Conflict of Interest}

Conflict of interest none declared

\section{REFERENCES}

Aderolu, A.Z., Seriki, B.M., Apatira, A.L and Ajaegbo, C.U. (2010). Effects of feeding frequency on growth, fed efficiency and economic viability of rearing African catfish (Clarias gariepinus, Burchell 1822) fingerlings and juveniles. African Journal of Food Science 4(5): 286-290.

Agung, S. (2004). Comparision of Lupin meal based diets cost efficiency for juvenile Penaeus monodon testes under pond condition. Journal of Coastal Development 8(1): 47-51. 
Oso

Bascinar Nadir., Cakmak Eyup., Cavdar Yahya., Aksungur Nilgun (2007). The effect of feeding frequency on growth performance and feed conversion rate of Black sea trout (Salmo trutta labrax Pallas, 1811). Turkish Journal of Fisheries and Aquatic Sciences 7: 13-17.

Cavero, B.A.S. (2004). Uso de enzimas digestives exo genas na alimentac a odo pirarucu, Arapaima gigas (curviewr, 1829). Pp. 74.

Davies, O.A., Inko-Tariah, M.B., Amachree, D. (2006). Growth response and survival of Heterobranchus longifilis fingerlings fed at different feeding frequencies. African Journal of Biotechnology 5: 778-787.

Ekelemu, J.K. and Ogba, O. (2005). Growth performance of Clarias gariepinus fed with ration of maggot meal as replacement of fish meal. In proceedings of the $20^{\text {th }}$ Annual Conference of the Fisheries Society of Nigeria (FISON) Porthacourt, $14^{\text {th }}-18^{\text {th }}$ November, 2005. Pp. 159162.

Ekelemu, J.K. and Zelibe, S.A.A. (2006). Growth patterns and condition factors of four dominant fish species in Ona lake, Southern Nigeria. Journal of Fisheries International 1 (2-4): 157-162.
Sci. Technol. Arts Res. J., July-Sep 2015, 4(3): 98-100

Gokcet, C.K., Mazium, Y. and Akyurt, I. (2008): Effect of feeding frequency on the growth and survival of Himri Barbel Barbus luteus (Heckel, 1843), Fry under laboratory conditions. Pakistan Journal of Nutrition 7(1): 66-67.

Hung, L.T., Tuan, N.A. and Lazard, J. (2002). Effects of feeding frequency and time of feeding on growth and feed utilization in two Asian catfishes, Pangasius bocourti (Sauvage, 1880) and P. hypopthatmus. (Sauvage 1978). Journal of Aquaculture in the Tropics 16(2): 171-184.

Idodo-Umeh, G. (2003): Fresh water fishes of Nigeria, IdodoUmeh publishers Ltd. Benin City. Pp 232.

Marimuthu, K., Ang Chi Cheen and Muralikrishnan, S. and Kumar, D. (2010). Effect of different feeding frquency on the growth and survival of African catfish, (Clarias gariepinus) fingerlings. Advances in Environmental Biology 4(2): 187-193.

Chris B. Ndome, A.O. Ekwu and Alfred A. Ateb (2011). Effect of feeding frequency on feed consumption, growth and feed conversion of Clarias gariepinus $\hat{\sigma} \mathrm{X}$ Heterobranchus longifilis +9 hybrids. American-Eurasian Journal of Scientific Research 6(1): 6-12. 